\title{
PERSPEKTYWY AKSJOLOGII PRAWA PRACY W DOBIE GLOBALIZACJI EKONOMICZNEJ
}

\section{WSTEP}

Zgodnie z neoklasyczną mikroekonomią nawiązanie stosunku pracy oznacza zarówno dla pracownika, jak i pracodawcy rezygnację z pewnego dostępnego im dobra (odpowiednio - wolnego czasu i pieniędzy), na rzecz innego dobra, które jest się $\mathrm{w}$ stanie uzyskać dzięki pracy albo świadczeniom majątkowym otrzymywanym od drugiej strony ${ }^{1}$. Ponieważ chęć uzyskania jak największego dobra jak najmniejszym kosztem często prowadzi do zdobycia faktycznej przewagi przez tę stronę, dla której osiągnięcie zakładanego przez nią celu nie jest uzależnione wyłącznie od pozostawania w konkretnym stosunku pracy, uznawaniu rynkowej ekwiwalentności świadczeń może towarzyszyć powstanie nierówności między pracownikiem a pracodawca na poziomie podmiotowym. Fakt, że wartość wymienna pracy ze względu na jej łatwą zastępowalność jest często niższa niż wartość, którą zatrudniający byłby jej w stanie przypisać w warunkach niedoboru siły roboczej, powoduje, iż możliwość kształtowania swojej sytuacji przez zatrudnianych staje się w wysokim stopniu iluzoryczna. Z tego względu zrzeszanie się stanowi dla pracowników podstawowy instrument służący wyrażaniu woli w sposób ważny z punktu widzenia pracodawcy w procesie uzgadniania kwestii dotyczących warunków wykonywania pracy. Już w Badaniach nad natura $i$ przyczynami bogactwa narodów Adam Smith zauważył, że: ,,pracodawcy, jako mniej liczni, o wiele łatwiej mogą się zrzeszać; prócz tego jeszcze prawo uznaje ich zrzeszenia, lub przynajmniej ich nie zabrania, zakazuje zaś związki robotnicze"2. Obecnie, mimo że organizowanie się pracowników w grupy interesu dopuszczone jest na płaszczyźnie normatywnej, to na poziomie faktycznym, w wyniku poszerzania zakresu stosowania regulacji cywilnoprawnej oraz jednostronnego kształtowania sytuacji zatrudnionych, zmierza się do wyłączenia wspólnotowego aspektu funkcjonowania uczestników rynku pracy.

W tych warunkach na prawie pracy spoczywa ciężar zapewnienia mechanizmu wyważania sprzecznych interesów, między innymi poprzez zapewnienie pracującym pozycji równoprawnych uczestników prowadzonego dyskursu.

\footnotetext{
${ }^{1}$ N. G. Mankiw, M. P. Taylor, Mikroekonomia, Warszawa 2009, s. 503.

2 A. Smith, Badania nad natura i przyczynami bogactwa narodów. Księga I, Warszawa 2003, s. 97-98.
} 
Ukierunkowanie zmian w porządku społecznym wymaga uświadomienia sobie, jakie stany rzeczy maja zostać osiaggnięte w wyniku ustanowienia norm prawnych, które będą stosowane i interpretowane w oderwaniu od ukierunkowania na wartości ${ }^{3}$. Punktem wyjścia rekonstrukcji realizowanych przez prawo pracy wyobrażeń na temat stanów rzeczy powiązanych $\mathrm{z}$ praca jest ustalenie systemowych perspektyw dotyczących pozycji człowieka, będącego ostatecznym nośnikiem praw i wolności, względem normowanej rzeczywistości. Ponieważ międzynarodowe prawo pracy stanowi platformę wymiany rozwiązań, która pozwala na przekroczenie kontekstu lokalnych tradycji prawnych czy kulturowo osadzonych światopoglądów, rekonstrukcja przeprowadzona na podstawie właśnie aktów prawa międzynarodowego może zapewnić najbardziej uniwersalny rezultat. $\mathrm{Z}$ tego względu za zasadnicze dla dalszych rozważań należy uznać występujące $\mathrm{w}$ międzynarodowym prawie pracy rozróżnienie na podstawowe prawa pracownicze (labour rights bądź core labour standards) i standardy prawa pracy (labour standards).

Przez długi czas mianem standardów prawa pracy określało się wszelkie regulacje międzynarodowe wyznaczające prawa, które w państwach będących ich adresatami miały przysługiwać pracownikom jako prawa pracownicze. Wraz z rozpowszechnieniem się ideologii neoliberalizmu ${ }^{4}$ załamaniu uległy funkcjonujące $\mathrm{w}$ Europie modele państw dobrobytu, w konsekwencji czego nastąpiła zmiana podejścia do ochrony i opieki, jaka państwo powinno otaczać pracowników ${ }^{5}$. Dotychczasowe znaczenie straciły mnożące się konwencje i zalecenia uchwalane przez Międzynarodową Organizację Pracy ${ }^{6}$, ratyfikowane i wdrażane najczęściej przez państwa, w których już obowiązywały przepisy ustanawiające odpowiednie standardy ${ }^{7}$. Ze względu na zmianę kierunku prowadzenia dyskursu nad przyszłościa prawa pracy zaczęto wyraźnie oddzielać podstawowe prawa pracownicze od standardów prawa pracy, kładąc nacisk na promowanie tych pierwszych jako praw przypominających swym charakterem prawa człowieka ${ }^{8}$. Zdaniem Briana Langille’a podstawowe prawa pracownicze oznaczaja normy proceduralne, które pozwalaja pracownikom uczestniczyć $\mathrm{w}$ procesie uczciwego ustalania warunków pracy w ramach stosunków zbiorowych ${ }^{9}$. W przeciwieństwie do standardów prawa pracy nie gwarantują żadnych konkretnych rezultatów w relacjach między pracownikami a pracodawcami, za ich pomocą nie można przeprowadzić bezpośredniej interwencji na rynku pracy, stanowią one tylko narzędzie do wyrównywania sytuacji wyjściowej stron ${ }^{10}$. Oznacza to, że kryterium przyjętego podziału jest posiadanie przez prawa charakteru proceduralnego, a więc umożliwianie

\footnotetext{
${ }^{3}$ Por. J. Habermas, Faktyczność i obowiazywanie, Warszawa 2005, s. 274-279.

${ }^{4}$ G. Duménil, D. Lévy, Neoliberalna (kontr-)rewolucja, w: A. Saad-Filho, D. Johnston (red.), Neoliberalizm przed trybunatem, Warszawa 2009, s. 27.

${ }^{5}$ B. Hepple, Labour Laws and Global Trade, Oxford-Portland 2005, s. 35.

${ }^{6}$ Ibidem, s. 10.

${ }^{7}$ Ibidem, s. 43-46.

${ }^{8}$ Ch. Breining-Kaufmann, Globalisation and Labour Rights, Portland 2007, s. 70.

${ }^{9}$ J. Fudge, The New Discourse of Labour Rights: From Social to Fundamental Rights?, „Comparative Labor Law and Policy Journal” 29, 2007, nr 1, s. 58-59.

${ }^{10}$ Ibidem, s. 59.
} 
działania, bądź posiadanie charakteru materialnego, czyli wywoływanie konkretnych rezultató $\mathrm{w}^{11}$. Istotniejsze wydaje się jednak to, że podczas gdy standardy prawa pracy odnoszą się bezpośrednio do urynkowionej sytuacji człowieka, to podstawowe prawa pracownicze gwarantuja pracownikom podmiotowość niezależną od kontekstu konfliktu jakichkolwiek interesów.

\section{PODSTAWOWE PRAWA PRACOWNICZE}

W 1998 r. Międzynarodowa Organizacja Pracy uchwaliła Deklarację dotycząca podstawowych zasad i praw w pracy. Zgodnie z jej tekstem 1) swoboda zrzeszania się oraz efektywnego uznania prawa rokowań zbiorowych, 2) likwidacja wszelkich form pracy przymusowej lub obowiązkowej, 3) skuteczna likwidacja pracy dzieci i 4) likwidacja dyskryminacji w zatrudnieniu i w zakresie wykonywania zawodu, to zasady, które szanować, promować i realizować muszą wszystkie państwa, bez względu na dokonanie ratyfikacji poszczególnych konwencji. Prawa podstawowe, które można z nich odtworzyć, traktować należy właśnie jako podstawowe prawa pracownicze. Przypominają one prawa człowieka pierwszej i drugiej generacji ${ }^{12}$, a więc prawa osobiste i polityczne. Zasadnicza różnica pomiędzy nimi a prawami socjalnymi, zaliczanymi do trzeciej generacji, polega na tym, że ustanawiaja wymóg szczególnego ukształtowania stosunków społecznych, nie zakładając przy tym redystrybucji żadnych dóbr.

Z paradygmatu neoklasycznej ekonomii można postawić zarzut, że przysługiwanie zatrudnionym prawa zrzeszania się w grupy interesu zaburza stosunki na wolnym rynku, powodując w konsekwencji niewynikający z wolnej konkurencji nadmierny wzrost siły przetargowej prcowników. Efektem tego miałaby być faktyczna redystrybucja dóbr, które na wolnym rynku pozostawałyby $\mathrm{w}$ posiadaniu pracodawców. Posługiwanie się takim argumentem wskazuje na pojmowanie wolnego rynku wyłącznie jako przestrzeni rywalizacji liczących się z realizacją indywidualnych interesów jednostek. Przyjęcie założenia, że jedyną płaszczyzną porozumienia jest zasada nieograniczonego współzawodnictwa, w szczególności w warunkach występowania skrajnej nierówności w zakresie dostępu do informacji czy realnej możliwości dyktowania warunków na rynku, nakazywałoby akceptowanie takich zjawisk, jak praca przymusowa. Gdyby założyć, że na wolnym rynku „każdy człowiek będzie liczył na własną swą siłę i sztukę, gdy chodzi o zabezpieczenie się przed innymi ludźmi, i będzie to czynił prawnie" ${ }^{13}$, to zupełnie pominie się fakt, iż mamy na nim do czynienia nie tylko ze współzawodnictwem (konkurencją), lecz także z koordynacją i współdziałaniem (kooperacją) wolnych ludzi, przy czym dla zapewnienia każdemu wolności niezbędne jest ustanowienie praw będących

\footnotetext{
${ }^{11}$ Ch. Breining-Kaufmann, op. cit., s. 70.

12 Podział praw człowieka na generacje jest krytykowany chociażby dlatego, że tworzy iluzję istnienia hierarchii praw, jednak mimo to wciąż bywa stosowany (J. Fudge, op. cit., s. 44).

13 T. Hobbes, Lewiatan, Kraków 1954, s. 148.
} 
gwarancja jej poszanowania. Podstawowe prawa pracownicze potrzebne sa nie po to, by usuwać nierówności w zakresie dostępu do dóbr, lecz mają one niwelować dysproporcje $\mathrm{w}$ zakresie możliwości korzystania przez strony stosunku pracy ze swoich praw osobistych.

Ponadto posiadanie przez pracowników szczególnych praw wynikających z pełnionej przez nich roli nie musi powodować pogorszenia się sytuacji ekonomicznej pracodawców. Odwołując się do tak zwanego dylematu więźnia $\mathrm{z}$ teorii gier ${ }^{14}$, Thomas Palley przytacza argument, zgodnie $\mathrm{z}$ którym w warunkach uniwersalnego obowiązywania podstawowych praw pracowniczych efektywność globalna rynków pracy byłaby wyższa niż w wypadku występowania miejsc, w których wskazane normy nie maja żadnej mocy ${ }^{15}$. Jednakże, mimo możliwości wysunięcia różnego rodzaju argumentów o charakterze ekonomicznym zarówno na rzecz, jak i przeciw podstawowym prawom pracowniczym ${ }^{16}$, to sam rachunek ekonomiczny nie stanowi wystarczającego uzasadnienia obowiązywania podstawowych praw pracowniczych. Niezbędne jest wykazanie, że zarówno one, jak i prawa osobiste posiadają równie silne lub wspólne uzasadnienie na gruncie przyjmowanych założeń dotyczących podstaw obowiązujących systemów normatywnych. W przeciwnym razie możliwe byłoby powoływanie się na wtórność i podrzędność norm zapewniających podmiotowość pracowników względem norm legitymizujących nabywanie ludzkiej pracy zgodnie z zasadami cywilnoprawnymi. Odwołując się do treści zasadniczych aktów prawa międzynarodowego i krajowego, należy wysnuć wniosek, że uzasadnieniem takim jest samocelowość człowieka, znajdująca najdobitniejszy wyraz w imperatywie praktycznym, nakazującym postępować tak, by człowieczeństwo tak w swojej osobie, jako też w osobie każdego innego używać zawsze zarazem jako celu, nigdy jako środka ${ }^{17}$. Współcześnie określana mianem godności, cecha ta jeszcze dla Immanuela Kanta znajdowała uzasadnienie w nieograniczonej wartości dobrej woli ${ }^{18}$. Dziś uznanie przysługiwania jej każdemu człowiekowi wydaje się założeniem systemowym, w stosunku do którego - ze względu na konieczność znalezienia ponadkulturowej płaszczyzny porozumienia - nie wysuwa się roszczenia do żadnej, wykraczającej poza nie samo podstawy.

Jako że prawo w dużym stopniu opiera się współczesnym nurtom filozofii krytycznej, które deprecjonują zarówno szczególne wyróżnienie człowieka w konstruowanych wizjach świata, jak i nieunikniony charakter zastanych tworów społecznych, założenie o przyrodzonej godności ludzkiej wciąż stanowi teoretyczna podstawę wszelkich praw i wolności. W art. 1 zdanie pierwsze Powszechnej deklaracji praw człowieka z 1948 r. wskazuje się na to, że ,,wszyscy rodzą się wolni i równi pod względem swej godności i swych praw". Zgodnie z orzecznictwem Europejskiego Trybunału Praw Człowieka „uznanie przyrodzonej godności każdej istoty ludzkiej”, o którym mowa w preambule do

${ }^{14}$ Por. H. R. Varian, Mikroekonomia, Warszawa 1997, s. 499.

15 T. Palley, The Economic Case for International Labour Standards, „Cambridge Journal of Economics" 28, 2004, s. 2.

${ }^{16}$ Por. J. Stiglitz, Employment, Social Justice and Social Well-Being, „International Labour Review” 141, 2002, nr 1-2, s. 10-13.

17 I. Kant, Uzasadnienie metafizyki moralności, Kęty 2009, s. 46.

${ }^{18}$ F. Ricken, Etyka ogólna, Kęty 2001, s. 109. 
Protokołu nr 13 do Konwencji o ochronie praw człowieka i podstawowych wolności, stanowi jedną z podstaw przyjętego w Konwencji systemu wartości ${ }^{19}$. $\mathrm{Z}$ kolei art. 30 Konstytucji RP wprost nakazuje traktować przyrodzona i niezbywalną godność jako ,źródło wolności i praw człowieka i obywatela” ${ }^{20}$.

W orzeczeniu Trybunału Konstytucyjnego (K 11/00) ${ }^{21}$ wskazuje się, że godność stanowi płaszczyznę odniesienia systemu wartości, na którym opiera się polski porządek prawny. Także w stanowiącej manifest współczesnego liberalizmu Teorii sprawiedliwości John Rawls, który nie wykluczał, że ludziom przypisać można różną wartość, zakładał jednocześnie, że są oni sobie „równi pod względem godności, rozumiejąc przez to tylko to, że wszyscy spełniaja warunki osobowości moralnej wyrażone w interpretacji wyjściowej sytuacji umowy. I będąc pod tym względem jednakowi, mają być traktowani, jak tego wymagaja zasady sprawiedliwości”"22.

Posługując się językiem etyki dyskursu, należałoby powiedzieć, że generalnym zadaniem wyróżnienia godności ludzkiej jest normatywne zagwarantowanie każdemu człowiekowi możliwie najszerszego zakresu równych podmiotowych wolności działania strategicznego ${ }^{23}$, czyli zorientowanego na indywidualny sukces działającego, oraz komunikacyjnego, a więc nastawionego na integrację $\mathrm{z}$ innymi podmiotami ${ }^{24}$. Jeśli przyjąć takie znaczenie godności, nasuwa się wniosek, że niedopuszczalne jest tworzenie sytuacji prawnej, w której interes podmiotu korzystającego z posiadanych wolności działania samodzielnego, jak i działania $\mathrm{w}$ porozumieniu, uzasadnia ograniczenie podobnych wolności innych, związanych z nim więzią strategiczną podmiotów. W tym kontekście podstawowe prawa pracownicze stają się koniecznym ekwiwalentem praw osobistych, gwarantując podmiotowość tym, którzy z racji przyjmowanej roli społecznej nie znajduja jej gwarancji w prawach zabezpieczających przede wszystkim swobodę kształtowania woli przez arbitralnie wybrane przesłanki.

\section{STANDARDY PRAWA PRACY}

Odmienną rolę należy przypisać standardom prawa pracy, którymi nazwać można te regulacje, które wyznaczają określone minimum w zakresie warunków zawiązywania, trwania i rozwiązywania stosunków pracy. Odnoszą się one do tych aspektów stosunku pracy, które stanowią bądź stanowiły obszar ścierania się interesów pracowników i pracodawców, a więc - do norm czasu pracy, poziomu bezpieczeństwa jej wykonywania, wysokości i sposobu przyznawania wynagrodzenia, zakresu odpowiedzialności stron czy warunków składania oświadczeń woli.

${ }^{19}$ Wyrok w sprawie Tyrer, par. 33; za: L. Garlicki (red.), Konwencja o ochronie praw człowieka i podstawowych wolności. Komentarz do artykutów 1-18, t. 1, Warszawa 2010, s. 19-20.

${ }^{20}$ Dz. U. 1997, Nr 78, poz. 483 ze zm.

${ }^{21}$ Wyrok TK z 4 kwietnia 2001 r., K 11/00, OTK 2001, nr 3, poz. 54.

22 J. Rawls, Teoria sprawiedliwości, Warszawa 2009, s. 475.

23 J. Habermas, op. cit., s. 138.

${ }^{24}$ Ibidem, s. 44. 
Jako pierwotne przyczyny ustanawiania tego typu norm wymienia się chęć zadbania o interesy pracowników (przede wszystkim związane $\mathrm{z}$ bezpieczeństwem i ochrona zdrowia) oraz uniknięcia konkurencji między przedsiębiorcami $^{25}$. W 1905 i 1906 r. z inicjatywy Międzynarodowego Stowarzyszenia Prawnej Ochrony Pracowników uchwalono konwencję zakazująca używania białego fosforu do produkcji zapałek oraz nakazująca ochronę pracy kobiet w porze nocnej ${ }^{26}$. Wraz z powstaniem w 1919 r. Międzynarodowej Organizacji Pracy zagadnienia związane $\mathrm{z}$ praca zaczęły być rozpatrywane $\mathrm{w}$ skali światowej. Zgodnie treścią części trzeciej Deklaracji filadelfijskej z 1944 r. zadaniem Międzynarodowej Organizacji Pracy jest popieranie programów, które mają doprowadzić między innymi do pełnego zatrudnienia i podniesienia poziomu życia, sprawiedliwego podziału dóbr uzyskiwanych w drodze postępu czy zagwarantowania bezpiecznych i nienarażających na utratę zdrowia warunków zatrudnienia. Wśród aktów MOP, które można uznać za sztandarowe przykłady źródeł standardów prawa pracy, wymienić można Konwencję nr 95 dotycząca ochrony płacy, gwarantująca wypłatę wynagrodzenia w pieniądzu służącym jako oficjalny środek płatniczy, wprowadza ograniczenia w zakresie potrąceń wynagrodzenia oraz zapewnia bezpośredni odbiór wynagrodzenia przez pracownika ${ }^{27}$, a także Konwencję $\mathrm{nr} 47$, zgodnie z która tygodniowa norma czasu pracy zostaje obniżona do czterdziestu godzin ${ }^{28}$.

Odchodząc od rozróżnienia standardów prawa pracy ze względu na ich materialnoprawny charakter, można przyjąć, że stwarzane za ich pomocą stany rzeczy zawsze dotycza faktycznej pozycji człowieka na rynku pracy. Tak więc bezpośrednim uzasadnieniem dla nich jest nie opisywany wyżej przymiot godności, lecz raczej godziwość, rozumiana jako pewien standard związany z zakresem dysponowania przez określony krąg podmiotów swoimi konkretnie pojmowanymi wolnościami. Gdyby przyjąć, że zasada uznania niezbywalnej godności stanowi bezpośrednie uzasadnienie standardów prawa pracy, wówczas należałoby także uznać rodzajowo podobne prawo pracodawców do osiągania minimalnego zysku z prowadzonej działalności. Takie prawo nie wydaje się ani racjonalne, ani sprawiedliwe, podczas gdy w warunkach zagrożenia zaniżaniem płac funkcjonuja normy wprowadzające najniższe dopuszczalne stawki wynagrodzenia. Skoro pracodawca może wymagać określonego poziomu staranności przy wykonywaniu zlecanych zadan, to oczekiwanie minimalnej zapłaty z tytułu wykonywanej pracy, której konieczną cechą jest odpłatność, nie wydaje się absurdalne.

Podczas gdy uzasadnieniem podstawowych praw pracowniczych jest określona, w pełni inkluzywna wizja podmiotowości człowieka, standardy prawa pracy odnoszą się do rynku i jego zawodności, a ich treść może być kształtowana $\mathrm{w}$ wyniku ścierania się przeciwstawnych interesów. Z tego względu standardy prawa pracy powinny służyć przeciwdziałaniu sytuacji,

${ }^{25}$ A. M. Świątkowski, Międzynarodowe prawo pracy, t. 1: Międzynarodowe publiczne prawo pracy, vol. 1 , Warszawa 2008 , s. XI.

${ }^{26}$ Ibidem, s. XIII.

${ }^{27}$ Konwencja (nr 95) dotycząca ochrony płacy, przyjęta w Genewie dnia 1 lipca 1949 r. (Dz. U. 1955 Nr 38, poz. 234).

${ }^{28}$ Konwencja ( $\mathrm{nr} 47$ ) dotycząca skrócenia czasu pracy do czterdziestu godzin tygodniowo. 
w której pracownicy traktowani są w sposób niegodziwy. Aby wyjaśnić znaczenie niegodziwości i zaproponować sposób jej oceny, warto odwołać się do narzędzi, które dostarcza filozofia Amartyi Sena.

Głównym celem jego koncepcji zdolnościowej (capabilities approach) jest przedstawienie stanowiska, zgodnie z którym kryterium ewaluacji struktur społecznych powinien być zakres, w jakim jednostka jest w stanie realizować swoje indywidualne wolności ${ }^{29}$. Zadanie, jakie postawił sobie Sen, polega na zaprezentowaniu alternatywy dla koncepcji sprawiedliwości nakazujących oceniać dobrobyt społeczeństw pod względem zasad dokonywania dystrybucji i redystrybucji dóbr. Zdaniem Sena podstawowym zadaniem społeczeństwa nie jest stwarzanie instytucji, za pomocą których w sposób bezstronny będzie się dokonywać redystrybucji dóbr ${ }^{30}$, gdyż faktyczna różnorodność sposobów, na jakie ludzie mogliby chcieć żyć, podważa zasadność sprowadzania szczęścia czy użyteczności do jednolitych kategorii ${ }^{31}$. Każdemu człowiekowi przypisać można za to określone sposoby funkcjonowania (functionings), przez które rozumie się sposoby bycia i działania (beings and doings) przez niego cenione ${ }^{32}$. Jako przykłady takich sposobów funkcjonowania można wymienić bycie zdrowym, szczęśliwym, szanowanym czy bycie członkiem określonej wspólnoty. Przez zdolności (capabilities) Sen rozumie ,różnorodne kombinacje sposobów funkcjonowania (bycia i działania), które człowiek może osiągnąć” ${ }^{33}$. Są one wyrazem zakresu wolności przysługującej człowiekowi i odzwierciedlają to, jak rzeczywiście jest on $\mathrm{w}$ stanie ją wykorzystać. Właśnie zakres dostępnych członkom danego społeczeństwa wolności może stanowić miarę rozwoju ${ }^{34}$, a instrumentem zwiększania możliwości, które jednostki są w stanie wykorzystywać, jest polityka społeczna ${ }^{35}$.

Opierając się na powyższych założeniach, za zasadne należy uznać ustanawianie takich norm prawa pracy, których obowiązywanie będzie prowadzić do rozszerzania zakresu wolności indywidualnych poszczególnych pracowników. W tym świetle podstawowe prawa pracownicze gwarantują uznanie wolności pracowników za wartość, której stopień ochrony należy negocjować w ramach ustanawiania standardów prawa pracy. Poszerzanie zakresu możliwości,jakimi dysponują pracownicy w wyniku zagwarantowania im prawa do urlopu o określonej długości czy minimalnego wynagrodzenia, powoduje jednocześnie ograniczenie możliwości, jakimi dysponują pracodawcy, których sfera wolności w zakresie dysponowania zasobami pracy ulega zmniejszeniu. Z perspektywy koncepcji zdolnościowej znajdowanie rozwiązań kompromisowych konieczne do zapewnienia względnej ekwiwalentności świadczeń, wynikającej z samego

${ }^{29}$ S. Alkire, Using the Capability Approach: Prospective and Evaluative Analyses, w: A. Alkire, M. Qizilbash, F. Comim (red.), The Capability Approach, Cambridge 2009, s. 28.

${ }^{30}$ Ustalanie reguł redystrybucji dóbr ma być u Rawlsa zgodne z jego drugą zasadą sprawiedliwości (idem, op. cit., s. 107).

${ }^{31}$ M. Qizilbash, Amartya Sen's Capability View: Insightful Sketch or Distorted Picture?, w: A. Alkire, M. Qizilbash, F. Comim (red.), op. cit., s. 55.

${ }^{32}$ A. Alkire, M. Qizilbash, F. Comim, Introduction, w: iidem (red.), op. cit., s. 2.

33 Ibidem.

34 Ibidem, s. 33.

${ }^{35}$ A. Sen, Rozwój i wolność, Poznań 2002, s. 32; idem, Nierówności. Dalsze rozważania, Kraków 2000, s. 18 . 
charakteru stosunku pracy, ze strony pracowników powinno opierać się o argument niegodziwego traktowania, to jest wystapienia uzasadnionego ograniczenia ich sfery wolności. Samo regularne podporządkowywanie się celom pracodawcy stanowi istotne ograniczenie wolności indywidualnej, jednak jest ono wpisane $\mathrm{w}$ istotę stosunku pracy. Do relacji dysfunkcyjnej dochodzi wówczas, gdy realizacja interesów pracodawcy usprawiedliwia unikanie dokonywania adekwatnej rekompensaty za fakt pozostawania w stosunku podrzędności organizacyjnej oraz niemożliwości alternatywnego wykorzystania czasu, a także stwarzanie takich warunków pracy, na które osoby nieprzymuszone sytuacją ekonomiczna lub osobistą nie wyraziłyby zgody. Ocena tego, czy dochodzi do dysfunkcji, zależy od indywidualnych odczuć, w związku z czym uznanie zasadności ustanawiania standardów prawa pracy podlega dyskusji i następuje w konsekwencji wyważania różnych, często sprzecznych interesów.

\section{KONFLIKTY INTERESÓW A WARTOŚCI REALIZOWANE PRZEZ PRAWO PRACY}

Uznanie częściowej autonomii podmiotów uzgadniających treść wzajemnych obowiązków ${ }^{36}$ dotyczących relacji zatrudniania powoduje powstanie wielości osadzonych we wspólnych ramach i funkcjonujących często horyzontalnie regulacji z zakresu prawa pracy. Źródła prawa pracy obejmują zarówno powszechnie obowiązujące prawo stanowione, które tworzone jest przy udziale reprezentantów zainteresowanych grup, jak i wprowadzone do krajowych porządków prawnych różnego pochodzenia akty prawa międzynarodowego, a także najniższe rangą akty autonomiczne, występujące w Polsce pod postacią układów zbiorowych, porozumień zbiorowych, regulaminów i statutów. Jeśli weźmie się ponadto pod uwagę fakt, że ze względu na upowszechnienie neoliberalnego modelu gospodarki globalnej prawo pracy musi konkurować z międzynarodowym prawem handlowym, to okaże się, że niemożliwe jest skonkretyzowanie spójnego systemu wartości realizowanych przez prawo pracy na poziomie globalnym. Korzystając z założeń dotyczących charakteru podstawowych praw pracowniczych i standardów prawa pracy, można za to wskazać zbiór wartości, których realizacji prawo pracy powinno przeciwdziałać. Próba zdominowania debaty nad zasadnością obowiązywania norm prawa pracy przez prowadzenie narracji wysuwającej na pierwszy plan kontekst interesów korporacyjnych stanowi działanie wymierzone przeciw fundamentom porządku prawnego będącego ostoją sfery publicznej.

Skutecznemu przeciwstawieniu się zjawiskom zglobalizowanego rynku pracy, polegającym na poszerzeniu zakresu szeroko rozumianej odpowiedzialności zatrudnionych, przy jednoczesnym zwiększaniu swobody zatrudniających, nie sprzyja niejednolitość prawa pracy na poziomie międzynarodowym. Do jego źródeł należą zarówno traktaty stanowione przez organizację międzynarodowe (treaty laws), jak i prawa negocjowane przez państwa członkowskie (treaty contracts $)^{37}$. Ponadto wskazuje się, że konwencje i zalecenia Międzynarodowej

${ }^{36}$ Por. L. Florek, Ustawa i umowa $w$ prawie pracy, Warszawa 2010, s. 111-121 i 178-180.

${ }^{37}$ A. M. Swiątkowski, op. cit., s. 51. 
Organizacji Pracy, które stanowią jedno z najczęściej dyskutowanych źródeł międzynarodowego prawa pracy, ze względu na sposób ustanawiania stanowią formę pośrednia między tymi dwoma typami aktów prawnych ${ }^{38}$. Obowiązywanie konwencji MOP opiera się nie tylko na członkostwie państw w organizacji, ale także na lojalności wobec tych państw, które wprowadziły konwencję do swojego krajowego porządku prawnego. Jeżeli większość państw ratyfikowała daną konwencję, to na pozostałych państwach także ciąży (nieformalny) obowiązek przestrzegania jej norm. Poza tym konwencja wchodzi do obrotu międzynarodowego wówczas, gdy ratyfikuje ją ustalona w niej liczba członków organizacji. Obecna słabość regulacji konwencyjnych mogła być ponadto jeszcze wyraźniejsza, gdyby aprobatę zyskał wysuwany postulat regionalizacji standardów prawa pracy. Argumentem na jego rzecz była odmienność sytuacji, w jakich znajdują się pracownicy w państwach różnych regionów świata. Nie został on jednak zrealizowany ze względu na zagrożenie utraty zasadności funkcjonowania światowej organizacji pracy, na co MOP nie mogła przystać ${ }^{39}$.

Jednakże, aby nie traktować problemów związanych $\mathrm{z}$ praca $\mathrm{w}$ różnych częściach świata w sposób jednolity, zaczęto stosować tak zwane elastyczne klauzule (flexibility clauses) w konwencjach i zaleceniach, które różnicuja obowiązki dla państw znajdujących się $\mathrm{w}$ różnym położeniu ${ }^{40}$. Zapewniały one istnienie: 1) opcji wyboru zobowiązań (umożliwiającą ratyfikację tylko części konwencji), 2) opcji ograniczenia zakresu podmiotowego (umożliwiająca stosowanie konwencji tylko do niektórych kategorii osób lub w ograniczonym zakresie przestrzennym), 3) opcji wyboru celów (oznaczającą zezwolenie na realizację określonego programu polityki społecznej) oraz 4) opcji wyboru środków (będące upoważnieniem do wyboru technik podejmowanych z myślą o osiagnięciu zamierzonego celu ${ }^{41}$. Choć niejednolite traktowanie państw znajdujących się w różnym położeniu uzasadnione jest celami ustanawiania standardów prawa pracy, czyli znajdowaniem odpowiedzi na faktycznie występujące nierówności na rynku pracy, to nie wpływa ono jednak na upraszczanie struktury międzynarodowego prawa pracy.

Pełni obrazu dopełniaja nieratyfikowane konwencje i zalecenia MOP, które nie sa źródłami prawa pracy, ale można powiedzieć, że wyznaczają pewne oczekiwania względem tego, jak stosunki pracy powinny być ukształtowane. Można powiedzieć, że określają one wartości, co do których postuluje się, by były celami, choć zgodnie z przyjęta procedurą legislacyjną nie zostały przyjęte do realizacji w wyniku ustanowienia norm. Zalecenia i inne podobne akty (np. deklaracje), które $\mathrm{z}$ założenia nie miały posiadać mocy aktów normatywnych, określa się miałem „,miękkiego prawa” (soft law). Ich znaczenie wyraźnie wzrosło w okresie ostatnich dwudziestu lat, czego powodem był brak woli oraz realnej możliwości ustanawiania wiążących aktów międzynarodowego prawa pracy ${ }^{42}$. Zaczęły one służyć także jako narzędzia

\footnotetext{
${ }^{38}$ Ibidem, s. 53.

${ }^{39}$ Ibidem, s. 55 .

${ }^{40}$ Ibidem, s. 56.

41 Ibidem.

42 J. Fudge, op. cit., s. 38.
} 
harmonizacji międzynarodowego prawa pracy i zasad międzynarodowego handlu. Istotną cechą aktów miękkiego prawa stało się to, że zaczęto używać ich jako narzędzia służącego promowaniu podstawowych praw pracowniczych jako praw człowieka. Deklaracja dotycząca podstawowych zasad i praw w pracy, opisana w rozdziale drugim, nie jest jedynym przykładem takiego dokumentu. Za istotny można uznać także projekt ONZ o nazwie „Globalne porozumienie”, na który składa się dziesięć zasad dotyczących przestrzegania i promowania praw człowieka, praw pracowniczych (identycznych z tymi wynikającymi z Deklaracji MOP z 1998 r.) oraz ochrony środowiska ${ }^{43}$. Roszczenie do uniwersalności, które stawiają, nie jest poparte żadnymi zinstytucjonalizowanym przymusem. Choć znaczenie tych dokumentów można uzasadniać teoretycznie i mogą one stanowić inspirację do rozważań nad implementacja zasad moralnych na rynkach pracy ${ }^{44}, \mathrm{w}$ praktyce wysuwane sa wnioski co do ich, z punktu widzenia mocy wiążącej, fasadowego charakteru. Na wskazane akty nie można powołać się chociażby przed sądami krajowymi ${ }^{45}$. Jednakże zauważa się, że chociaż same w sobie nie stanowią źródeł „twardego” prawa, to przyczyniły się do wzmożenia procesu wdrażania międzynarodowych standardów prawa pracy do krajowych porządków prawnych ${ }^{46}$.

Nadawanie znaczenia wartościom bez nadawania im demokratycznej legitymacji normatywnej popartej instytucjami egzekwowania ma współcześnie jeszcze jeden wymiar. Od lat osiemdziesiątych $\mathrm{XX}$ w. praktyką stało się upowszechnianie korporacyjnych kodeksów etycznych (codes of practice). Zjawisko to interpretowane bywa przez pryzmat przesunięcia się regulacji prawa pracy ze sfery publicznej do sfery prywatne ${ }^{47}$. Powodami zainteresowania korporacji ustanawianiem wewnętrznych norm regulujacych stosunki pracy sa, poza dążeniem do zwiększenia morale, a co za tym idzie - efektywności pracowników, chęć minimalizacji krytyki prowadzonej przez nie polityki, próba skorzystania z pozytywnych efektów ekonomicznych, jakie niesie ze soba podwyższenie standardu zatrudnienia oraz wzmocnienie pozycji centrali zarządzajacych korporacjami ${ }^{48}$.

Chociaż wskazane regulacje teoretycznie mogłyby wpływać na podwyższenie standardów pracy u pracodawców zatrudniających szerokie rzesze pracowników w państwach niezapewniających im odpowiedniej ochrony, to w rzeczywistości najczęściej sprowadzaja się one do pustych deklaracji ze względu na brak implementacji w oddziałach znajdujących się właśnie w tych państwach. Co więcej, wewnętrzne kodeksy etyczne są tworzone i monitorowane z pominięciem partycypacji pracowniczej ${ }^{49}$. Stan ten interpretować można jako próbę dostarczenia argumentu na rzecz niezasadności dopuszczania związków zawodowych do głosu w sprawie polityki zatrudnienia korporacji. Ostatecznym

\footnotetext{
${ }^{43}$ Ch. Breining-Kaufmann, op. cit., s. 160-161.

${ }^{44}$ A. Sen, Work and Rights, ,International Labour Review” 139, 2000, s. 123.

45 B. Hepple, op. cit., s. 83.

46 Ibidem, s. 60.

47 Ibidem, s. 70.

48 Ibidem, s. 71.

49 Ibidem, s. 75.
} 
celem korporacji, realizowanym przez tworzenie wewnętrznych regulacji dotyczących standardu pracy, jest zwiększanie autonomii w zakresie prowadzonej w skali światowej polityki zatrudnienia ${ }^{50}$.

Należy zauważyć, że znaczenie dla komplikowania sytuacji w prawie międzynarodowym ma prowadzenie między innymi przez Światową Organizacje Handlu (WTO) i Międzynarodowy Fundusz Walutowy (IMF) polityki podporządkowywania prawa pracy neoliberalnej koncepcji rozwoju. Promowanie własnych rozwiązań dotyczących zatrudnienia stanowi działanie konkurencyjne dla prowadzonej między innymi przez MOP promocji podstawowych praw pracowniczych i standardów prawa pracy. Sprzeciw wobec prób wprowadzania regulacji dotyczących standardów pracy do Układu Ogólnego w sprawie Taryf Celnych i Handlu (GATT) i aktów WTO spowodował przyjęcie w 1996 r. w Singapurze porozumienia w sprawie zaniechania wskazanej praktyki i wyraźnego rozdzielenia przedmiotu działalności MOP i WTO/ /GATT $^{51}$. Jednakże wzmacniające swoją pozycję od lat siedemdziesiątych XX w. IMF oraz Bank Światowy ${ }^{52}$ wciąż prowadzą politykę, która promuje własne, neoliberalne idee dotyczące roli prawa pracy ${ }^{53}$. Choć na aprobatę zasługuje powszechne uznanie przez te organizacje konieczności walki z praca dzieci i dyskryminacją $\mathrm{w}$ zatrudnieniu, to nie można zgodzić się z prezentowanym przez nie poglądem, że przyjęcie pozostałych założeń deklaracji MOP dotyczących podstawowych zasad i praw w pracy wymaga relatywizacji do poziomu rozwoju konkretnych państw ${ }^{54}$. Ten aspekt działalności międzynarodowych instytucji finansowych jest przejawem zwiększania wpływu prywatnych graczy na scenie międzynarodowej.

Jako jedno z głównych źródeł zagrożeń dla przestrzegania prawa pracy w skali globalnej wymienia się właśnie działanie międzynarodowych korporacji. Reprezentuja one „kapitał” definiowany przez Urlicha Becka jako zbiór „nieskoordynowanych działań pojedynczych przedsiębiorców, strumieni finansowych, organizacji międzynarodowych (WTO, IMF itd.), których efekty - w sensie polityki skutków ubocznych - w sposób mniej czy bardziej niewidoczny, a nawet niechciany poddaja państwa naciskom i w ten sposób przyczyniają się do rozpadu »państwa narodowego « tradycyjnych warcabów" ${ }^{55}$. Celem tak rozumianego kapitału jest ,zespolenie się z państwem, aby w postaci państwa neoliberalnego szukać dla siebie nowej legitymizacji" ${ }^{56}$.

Korporacje, pełniące rolę nowych graczy na arenie międzynarodowej, starają się realizować ten cel. Ze względu na nieograniczony zasięg swojej działalności i wpływ, jaki wywierają one na politykę państw oraz organizacji międzynarodowych, są w stanie skutecznie uchylać się od obowiązków wynikających $\mathrm{z}$ międzynarodowych regulacji z zakresu prawa pracy ${ }^{57}$. Ponieważ korporacje

\footnotetext{
50 Ibidem, s. 85 .

51 Ch. Breining-Kaufmann, op. cit., s. 130.

${ }^{52}$ Ibidem, s. 101.

${ }^{53}$ Od 1989 r. IMF i Bank Światowy propagują zasady wyrażone w konsensusie waszyngtońskim, zgodnie z którym kluczem do rozwoju jest m.in. deregulacja rynku pracy (ibidem, s. 102).

${ }^{54}$ Ibidem, s. 106.

${ }^{55}$ U. Beck, Wtadza i przeciwwtadza w epoce globalnej, Warszawa 2005, s. 37.

56 Ibidem, s. 44.

${ }^{57}$ Ch. Breining-Kaufmann, op. cit., s. 156.
} 
realizują wyłącznie własne, partykularne interesy związane $\mathrm{z}$ osiaganiem jak najlepszych wyników finansowych w ramach ciagłego rozwoju, wspólnotowa perspektywa prawa pracy jest dla nich obca. Przestrzeganie przez nie prawa jest faktycznie uzależnione od możliwych do osiągnięcia korzyści politycznych i ekonomicznych. Z tego powodu przejmowanie kompetencji prawotwórczych w tych aspektach, które dotyczą ich działalności, stanowi racjonalne działanie we własnym interesie.

Organizacja Narodów Zjednoczonych podjęła kroki mające na celu obciążenie odpowiedzialnością za kontrolowanie korporacji państw, w których one funkcjonują. Mowa tu w szczególności o uchwalonej w 2003 r. normie dotyczącej odpowiedzialności międzynarodowych korporacji i innych przedsiębiorstw w stosunku do praw człowieka ${ }^{58}$. Opór zarówno większości państw, jak i korporacji wobec tej inicjatywy potwierdza tezę Ulricha Becka o zbliżeniu się interesów tych dwóch rodzajów aktorów. Bynajmniej nie jest to jednak tendencja ułatwiająca promocje praw człowieka i procesu prawdziwej demokratyzacji polegającej na szukaniu legitymacji prawa w woli społeczeństw.

Problem pogodzenia interesów korporacji z wymaganiami uniwersalnych norm prawa pracy, urzeczywistniającymi wartości wspólnotowe, polega na tym, że na poziomie praw pracowniczych jakikolwiek kompromis jest niemożliwy. Wynika to z nieporównywalności roszczeń wynikających z obowiązku poszanowania godności ludzkiej oraz poszanowania czyichkolwiek partykularnych interesów. Dyskusja nad przyjęciem standardów prawa pracy dopuszcza taki kompromis, gdyż zakres wynikających z nich uprawnień pracowniczych kształtowany jest przez porównywalne z interesami korporacji interesy pracowników.

Brak skutecznych środków egzekwowania przestrzegania przez korporacje podstawowych praw pracowniczych świadczy o bezsilności międzynarodowych, jak i krajowych instytucji. Uwzględnianie interesów gospodarczych w dyskusji nad obowiązywaniem i przestrzeganiem tych praw dowodzi zaś istnienia stanu „globalnego bezprawia”. Poszanowanie godności ludzkiej jest podstawa zarówno wolności osobistej, której przejawem jest możliwość realizacji interesów gospodarczych, jak i wolności pracowniczej. Przedkładanie interesów partykularnych nad aspekt ludzkiej godności związany z wykonywaniem pracy podważa założenie o godności w ogóle, a więc podkopuje także fundament pod wolności osobiste. $\mathrm{Z}$ tego właśnie względu zabezpieczenie poszanowania podstawowych praw pracowniczych jest niezbędne do uzyskania poczucia prawowitości prawa.

mgr Mateusz Madejski

mateusz.madejski@gmail.com

${ }^{58}$ Ibidem, s. 162. 


\section{AXIOLOGY OF LABOUR LAW IN THE AGE OF ECONOMIC GLOBALISATION}

\section{Summary}

A relation between acknowledging the binding force of law and sharing a vision of the world that people want to realise within the confines of being in a community, poses a problem that finds its reflection in the practice of modern labour law, which is considered by some as a tool necessary for fair regulation of relations in labour markets, and by others as an instrument disrupting 'free market' conditions, used to enforce private interests. Due to proliferation of the neoliberal pattern of global economy, justification of labour law has become an issue that goes beyond the context set by national borders. Today, when the idea of development on increasing effectiveness of international trade and making employment relations more flexible prevails, the meaning of international labour law lies not in stimulating 'developing' countries to pursue a typically protective policy of employment, but rather in providing grounds for a direct guarantee of minimum standards of labour conditions worldwide. The aim of this paper is to show that heading for full privatisation of issues concerning employment through giving employers excessive liberty to dispose of work, stands in contradiction with the basic premises of the legal framework of countries that belong to the international community. The reason for that lies it the common axiological grounds for both the core labour rights which provide participants of labour market with subjectivity, and the civil rights. 
Copyright of Journal of Law, Economics and Sociology is the property of Faculty of Law and Administration of Adam Mickiewicz University in Poznan and its content may not be copied or emailed to multiple sites or posted to a listserv without the copyright holder's express written permission. However, users may print, download, or email articles for individual use.

Właścicielem praw autorskich do „Ruchu Prawniczego, Ekonomicznego i Socjologicznego” jest Wydział Prawa i Administracji Uniwersytetu im. Adama Mickiewicza w Poznaniu. Zawartość czasopisma nie może być kopiowana, przesyłana do innych stron internetowych bądź zamieszczana na blogach bez pisemnej zgody wydawcy. Niemniej artykuły można drukować, kopiować lub przesyłać w formie elektronicznej na własny użytek. 